\title{
The Effects of Thermal and Atmospheric Pressure Radio Frequency Plasma Annealing in the Crystallization of $\mathrm{TiO}_{2}$ Thin Films
}

\author{
$\mathrm{Yu} \mathrm{Xu}{ }^{1,2}$, Yu Zhang ${ }^{2}$, Tao He ${ }^{2}$, Ke Ding ${ }^{2}$, Xiaojiang Huang ${ }^{2}, \mathrm{Hui} \mathrm{Li}^{2}$, Jianjun Shi ${ }^{2}$, Ying Guo ${ }^{2, *}$ \\ and Jing Zhang ${ }^{1,2}$ \\ 1 State Key Laboratory for Modification of Chemical Fibers and Polymer Materials and College of Materials \\ Science and Engineering, Donghua University, Shanghai 201620, China; 1142024@mail.dhu.edu.cn (Y.X.); \\ jingzh@dhu.edu.cn (J.Z.) \\ 2 College of Science, Donghua University, Shanghai 201620, China; 2161508@mail.dhu.edu.cn (Y.Z.); \\ 1169212@mail.dhu.edu.cn (T.H.); dingke@dhu.edu.cn (K.D.); huangxj@dhu.edu.cn (X.H.); \\ huili@dhu.edu.cn (H.L.); JShi@dhu.edu.cn (J.S.) \\ * Correspondence: guoying@dhu.edu.cn; Tel.: +86-021-67792088
}

Received: 24 April 2019; Accepted: 29 May 2019; Published: 31 May 2019

\begin{abstract}
Amorphous $\mathrm{TiO}_{2}$ thin films were respectively annealed by $13.56 \mathrm{MHz}$ radio frequency (RF) atmospheric pressure plasma at discharge powers of 40,60,80 W and thermal treatment at its corresponding substrate temperature $\left(T_{\mathrm{S}}\right)$. $T_{\mathrm{S}}$ was estimated through three measurement methods (thermocouple, Newton's law of cooling and $\mathrm{OH}$ optical emission spectra simulation) and showed identically close results of 196,264 and $322^{\circ} \mathrm{C}$, respectively. Comparing with thermal annealing, this RF atmospheric pressure plasma annealing process has obvious effects in improving crystallization of the amorphous films, based on the XRD and Raman analysis of the film. Amorphous $\mathrm{TiO}_{2}$ film can be changed to anatase film at about $264{ }^{\circ} \mathrm{C}$ of $T_{\mathrm{s}}$ for $30 \mathrm{~min}$ plasma treatment, while it almost remains amorphous after $322^{\circ} \mathrm{C}$ thermal treatment for the same time.
\end{abstract}

Keywords: amorphous $\mathrm{TiO}_{2}$ thin film; low temperature crystallization; RF atmospheric pressure plasma; thermal annealing

\section{Introduction}

Titanium dioxide $\left(\mathrm{TiO}_{2}\right)$ film has been extensively investigated in the last decades by many researchers. $\mathrm{TiO}_{2}$ is a kind of chemically stable and body-friendly semiconductor material with high refractive index [1], photocatalytic activity [2], and wide-band gap [3]. With these outstanding properties, $\mathrm{TiO}_{2}$ is widely used as a white pigment in paints, toothpastes [4], an antireflection coating [5], photocatalyst in environmental [6,7] and energy field [8,9], and a transport layer in dye-sensitized solar cell [10] and perovskite solar cells [11]. $\mathrm{TiO}_{2}$ has three naturally occurring polymorphs, anatase, brookite, and rutile [1]. Usually, anatase requires a substrate temperature over $450{ }^{\circ} \mathrm{C}$ and in excess of $550{ }^{\circ} \mathrm{C}$ to prepared rutile [12]. Anatase has larger band gap (3.2 eV) than that (3.0 eV) of rutile and the photocatalytic activity of anatase is obviously superior to that of rutile [13]. To reduce the crystallization temperature of anatase will broaden the application field of the $\mathrm{TiO}_{2}$.

RF plasma treatment has been developed to prepare anatase $\mathrm{TiO}_{2}$ film at low temperature [14-16]. The amorphous $\mathrm{TiO}_{2}$ film turn to anatase even at room temperature [14]. However, the treatment processes usually needs vacuum system.

Atmospheric pressure plasma is widely studied for a continuous process with reducing equipment and handling cost $[17,18]$. The synergistic effect of plasma deposition and substrate temperature in 
improving the crystallization of $\mathrm{TiO}_{2}$ film through atmospheric pressure $\mathrm{kHz}$ plasma has been found and studied in our previous work [19].

In this paper, we have investigated the crystallization process of amorphous $\mathrm{TiO}_{2}$ film annealed by RF atmospheric pressure plasma and its corresponding $T_{\mathrm{s}}$ thermal treatment. Amorphous $\mathrm{TiO}_{2}$ thin films were successfully crystallized through 30 min plasma annealing treatment of $60 \mathrm{~W}\left(T_{\mathrm{s}} \sim 264{ }^{\circ} \mathrm{C}\right)$. However, it is found that the films thermally treated with higher temperatures were still amorphous.

\section{Materials and Methods}

\subsection{Thin Films Deposition}

The amorphous $\mathrm{TiO}_{2}$ thin films were prepared by atmospheric pressure dielectric barrier discharges (AP-DBD) chemical vapor deposition. The experiment details can be found in our previous work [19]. The flow rates were set as $\mathrm{Ar}: \mathrm{O}_{2}: \mathrm{TiCl}_{4}$ (carrier gas) = 1000:10:25 (sccm). The temperature during deposition was not more than $50^{\circ} \mathrm{C}$. The deposition time was $30 \mathrm{~min}$. Quartz were used as substrates in the thin film deposition. The deposited $\mathrm{TiO}_{2}$ thin films are amorphous and used as original samples. The thicknesses of the films are about $105 \mu \mathrm{m}$.

\subsection{Plasma Treatment}

A RF Generator (13.56 MHz, RF-10S/PWT, Advanced Energy, Fort Collins, CO, USA) was used as power source in plasma annealing. The discharge chamber was made by quartz and the chamber wall is $1 \mathrm{~mm}$ thick. The discharge gap is $2 \mathrm{~mm}$. The films have been treated separately at three discharge power: 40,60 and $80 \mathrm{~W}$. Ar with the flow rate of $500 \mathrm{sccm}$ was used as the treatment gas. The treatment time is $30 \mathrm{~min}$. The waveforms of applied voltage and discharge current were measured by wideband voltage probes (Tektronix P5100, Beaverton, OR, USA) and wideband current probes (Pearson 2877, London, UK), and recorded on a digital oscilloscope (Tektronix DPO 4101). Optical emission spectra of the RF plasma were investigated by an optical emission spectrometry (OES, Avantes Avaspec-2048tec, Apeldoorn, The Netherlands). The schematic of the experimental setup is shown in Figure 1.

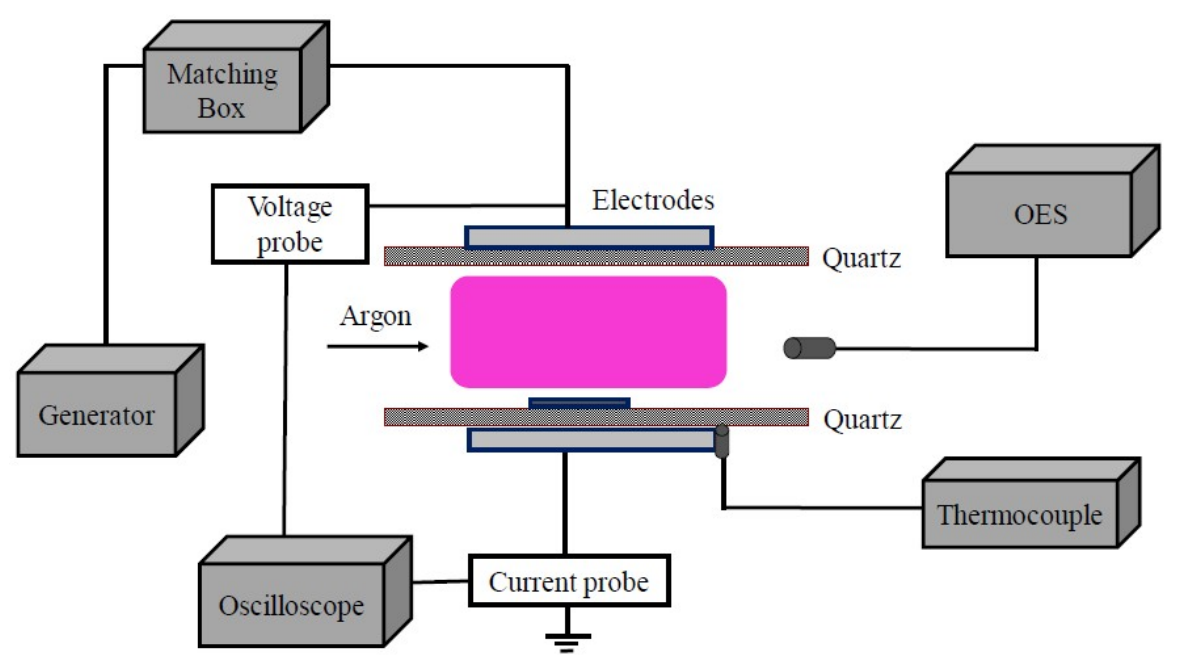

Figure 1. Schematic RF plasma treatment experimental set up.

\subsection{Temperature Measurement during Plasma Annealing}

Three test methods were used to estimate the substrate temperature during the discharge. (a) As shown in Figure 1, a thermocouple (TES1310, Taipei, Taiwan) was set between the bottom electrode and the chamber, where it is assumed the temperature is close to the substrate temperature during the plasma treatment. (b) After plasma treating, the temperature of the bottom electrode will decrease with time. By recording this temperature decreasing with time and using Newton's law of 
cooling, the original temperature of the electrode was calculated. (c) The gas temperature at different discharge powers is simulated by $\mathrm{OH}$ peak of the plasma OES.

\subsection{Heating Treatment}

The $\mathrm{TiO}_{2}$ films were heated in the same chamber with same Ar flow rate as plasma treatment. The heating temperatures were set following the temperatures of different power discharges. The treatment was $30 \mathrm{~min}$ as plasma treatment.

\subsection{Thin Films Analysis}

The samples were characterized by powder X-ray diffraction (XRD, Tokyo, Japan) measurements recorded with a Rigaku D/max-2550 PC X-ray diffractometer with a rotating anode and a Cu Ka radiation source $(\lambda=1.54056 \AA)$. Raman measurement was carried out using a Raman spectroscopy (Renishaw inVia-Reflex, Wotton-under-Edge, UK). The power of the laser was $5 \mathrm{~mW}$, and the laser excitation was $532 \mathrm{~nm}$. Scans were taken on an extended range $\left(100-800 \mathrm{~cm}^{-1}\right)$. The morphology of the obtained samples (original and P3) were determined with a field emission scanning electron microscope (FESEM, Hitachi, S-4800, Tokyo, Japan).

Methylene blue (MB, Sigma-Aldrich, St. Louis, MO, USA) was employed as dye to evaluate the photocatalytic activity of the films. The samples were settled in $20 \mathrm{~mL}$ of $5 \mathrm{mg} / \mathrm{L} \mathrm{MB}$ aqueous solution. The quartz container with the sample and solution was placed on a magnetic stirrer plate (Leici JB-1, Shanghai Leici Co., Ltd, Shanghai, China) and a stirrer bar placed in the solution. The photocatalytic reaction was conducted at room temperature under UV light (PLS-SXE300UV, Beijing Perfectlight Co., Ltd, Beijing, China). It provided $6.6 \mathrm{~W}$ ultraviolet light. The distance between the lamp and the base of the container was $1 \mathrm{~m}$. The decomposition of MB was monitored by measuring the absorbance of the aliquot solution using the UV-vis spectrophotometer (Shimadzu UV-2600, Kyoto, Japan) in liquid cuvette with deionized water as reference. The concentration of the MB solution was measured every $30 \mathrm{~min}$.

\section{Results and Discussion}

\subsection{I-V Curve and OES Test of the Discharge}

Figure 2a shows the voltage and current waveforms of argon RF discharge of $80 \mathrm{~W}$. The input peak-to-peak voltage $\left(V_{\mathrm{p}-\mathrm{p}}\right)$ is about $1800 \mathrm{~V}$, and the input peak-to-peak current $\left(C_{\mathrm{p}-\mathrm{p}}\right)$ is about $0.44 \mathrm{~A}$. The $V_{\mathrm{p}-\mathrm{p}}$ and $C_{\mathrm{p}-\mathrm{p}}$ of different treatment powers are shown in Table 1.

The OES of the $80 \mathrm{~W}$ RF plasma is shown in Figure $2 \mathrm{~b}$. The inset is the discharge photograph. The $\operatorname{Ar}(671.8 \mathrm{~nm}), \operatorname{Ar}(723 \mathrm{~nm})$ and other typical emission lines are shown out. Since the discharge is in atmospheric pressure, $\mathrm{OH}(309 \mathrm{~nm})$ [20], $\mathrm{N}_{2}(337.1,357.7,371.1 \mathrm{~nm})$ [21] and $\mathrm{O}(777.1 \mathrm{~nm})$ [22] are also shown out in the plasma.
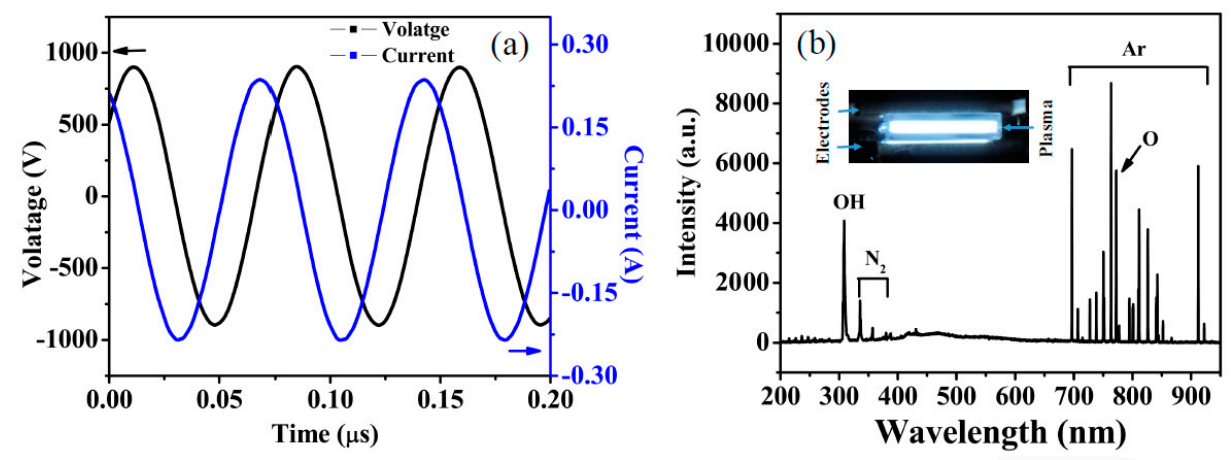

Figure 2. (a) Voltage and current waveforms of argon RF discharge of $80 \mathrm{~W}$; (b) OES spectrum of argon RF discharge. 
Table 1. The input voltage and current of different discharge powers.

\begin{tabular}{ccc}
\hline Power $(\mathbf{W})$ & $V_{\text {p-p }}(\mathbf{V})$ & $C_{\text {p-p }}(\mathrm{A})$ \\
\hline 40 & 1560 & 0.34 \\
60 & 1700 & 0.41 \\
80 & 1800 & 0.44 \\
\hline
\end{tabular}

\subsection{Temperature Measured}

Since temperature of discharge has great influence on crystallization and it is not easy to get the accurate substrate temperature during the plasma discharge. Three methods were employed to estimate the substrate temperature during plasma treatment at different discharge powers.

\subsubsection{Thermocouple}

By using thermocouple, the temperature of the bottom of chamber $\left(T_{\mathrm{c}}\right)$ is about $322^{\circ} \mathrm{C}$. And the temperatures measured at 40 and $60 \mathrm{~W}$ are 196 and $264{ }^{\circ} \mathrm{C}$ and shown in Table 2.

Table 2. The temperature at different power tested by different methods.

\begin{tabular}{cccc}
\hline Power $(\mathbf{W})$ & $\mathbf{4 0}$ & $\mathbf{6 0}$ & $\mathbf{8 0}$ \\
\hline$T_{\mathrm{C}}\left({ }^{\circ} \mathrm{C}\right)$ & 196 & 264 & 322 \\
$T_{\mathrm{o}}\left({ }^{\circ} \mathrm{C}\right)$ & 207 & 277 & 307 \\
$T_{\mathrm{n}}\left({ }^{\circ} \mathrm{C}\right)$ & 192 & 260 & 321 \\
\hline
\end{tabular}

\subsubsection{OH Peak Simulation}

The $\mathrm{OH}(309 \mathrm{~nm})$ rotational temperature are usually used to estimate the gas temperature of plasma $\left(T_{\mathrm{g}}\right)$ [23]. By using LIFBASE software (version 2.1.1), the $\mathrm{OH}$ rotational temperatures at discharge were simulated and the result at $80 \mathrm{~W}$ is shown in Figure 3. The simulated result show that the gas temperature was $307^{\circ} \mathrm{C}$. The gas temperature simulated with $\mathrm{OH}$ peak by OES $\left(T_{\mathrm{o}}\right)$ at discharge power of 40 and $60 \mathrm{~W}$ are 207 and $277^{\circ} \mathrm{C}$ and shown in Table 2.

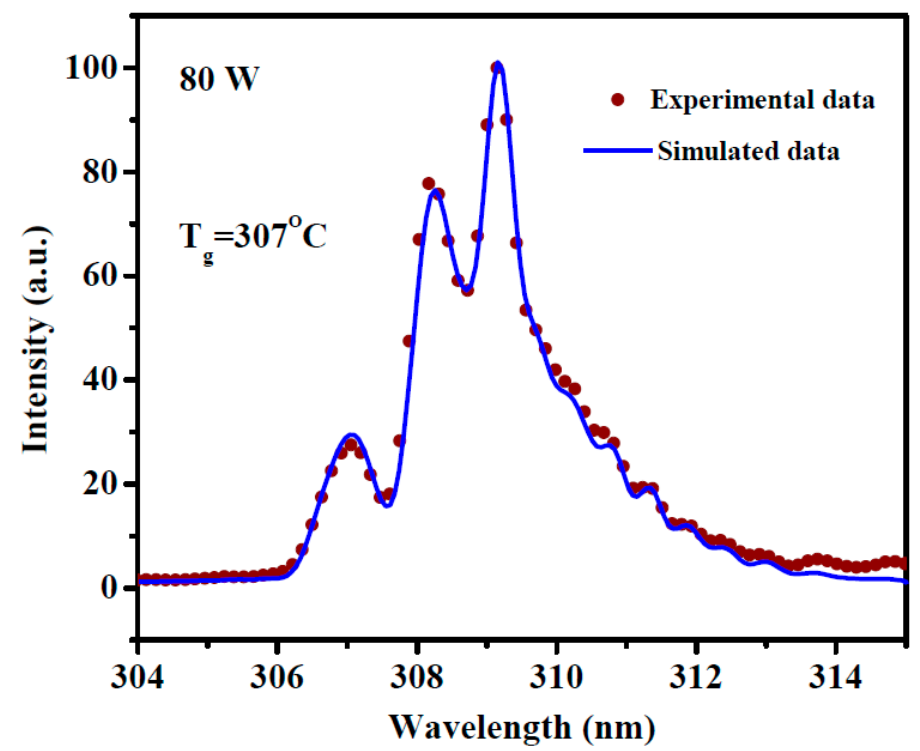

Figure 3. The simulation of $\mathrm{OH}(309 \mathrm{~nm})$ rotational temperature with OES of $80 \mathrm{~W}$ discharge.

\subsubsection{Newton's Law}

Newton's law of cooling demonstrates exponential cooling curve with time [24]. The electrode temperature changes with time are recorded and shown in Figure 4 until the temperature stabiles. 
The temperature changes from the beginning 2-39 s were inset in Figure 4 and fitted with Newton's law of cooling. We got the formula as follows,

$$
\begin{aligned}
& T=25+167 \cdot e^{\frac{-t}{201}}(40 \mathrm{~W}) \\
& T=25+235 \cdot e^{\frac{-t}{179}}(60 \mathrm{~W}) \\
& T=25+295 \cdot e^{\frac{-t}{162}}(80 \mathrm{~W})
\end{aligned}
$$

where, $T$ is the temperature $\left({ }^{\circ} \mathrm{C}\right)$ and $t$ is time (s). So, extending the curve to $t=0 \mathrm{~s}$, the plasma temperatures at different discharge powers $\left(T_{n}\right)$ are calculated and shown in Table 2.

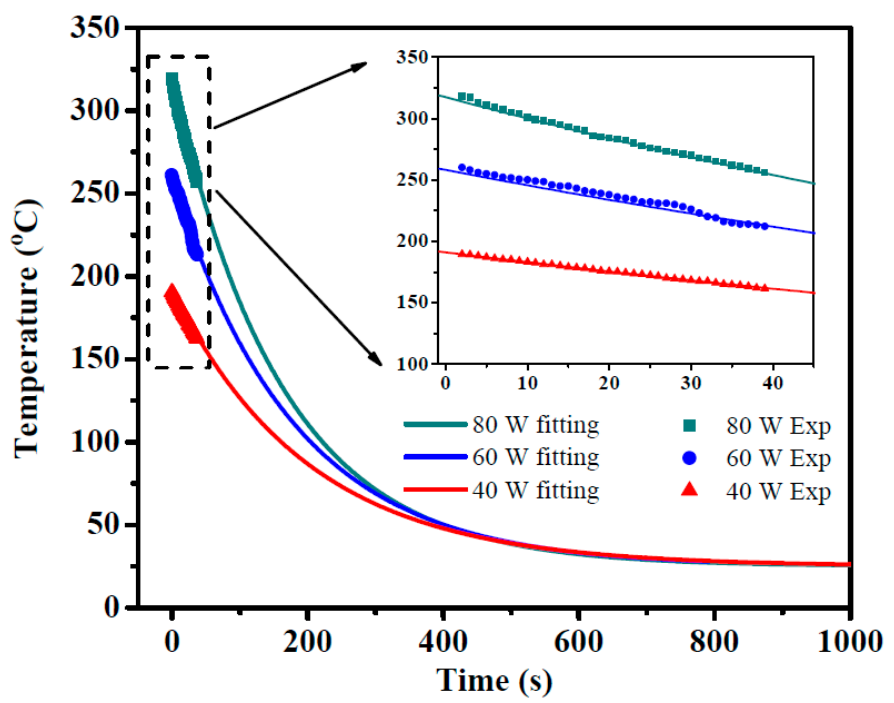

Figure 4. The temperature of electrode decreasing with time and fitted by Newton's law of cooling.

The thermocouple test temperature $\left(T_{\mathrm{c}}\right)$, gas temperature simulated by $\mathrm{OH}$ peak $\left(T_{\mathrm{o}}\right)$ and calculated temperature by Newton's law of cooling $\left(T_{\mathrm{n}}\right)$ are summarized in Table 2 . It is displayed $T_{\mathrm{C}}$, $T_{\mathrm{o}}$ and $T_{\mathrm{n}}$ are identically close at the same discharge power. They all show increasing trends with the increasing of the discharge power. The highest temperature is assumed not above $322{ }^{\circ} \mathrm{C}$ at the highest discharge power of $80 \mathrm{~W}$.

\subsection{Thin Film Characterization}

In order to compare the effects of thermal or plasma treatment in improving film crystallization, three amorphous films were respectively thermally treated at the same substrate temperature of 196, 264 and $322{ }^{\circ} \mathrm{C}$ as at three discharge powers. The same chamber and Ar gas flow rate are used to ensure the consistent treatment conditions, except the plasma discharge is off. The treated conditions and the sample names are given in Table 3.

Table 3. The sample name and the treatment conditions.

\begin{tabular}{cccccccc}
\hline Treatment Method & \multicolumn{3}{c}{ Plasma Treatment } & \multicolumn{3}{c}{ Heating Treatment } \\
\hline Sample Name & Original & P1 & P2 & P3 & H1 & H2 & H3 \\
\hline Treatment condition & As deposited & $40 \mathrm{~W}$ & $60 \mathrm{~W}$ & $80 \mathrm{~W}$ & $196{ }^{\circ} \mathrm{C}$ & $264{ }^{\circ} \mathrm{C}$ & $322{ }^{\circ} \mathrm{C}$ \\
\hline
\end{tabular}

The XRD spectra of samples treated by plasma and heating are respectively shown in Figure 5a,b. The original sample as deposition is amorphous. The XRD spectrum of sample P1 treated by $40 \mathrm{~W}$ plasma, in Figure 5a shows weak (101) peak at $2 \theta$ values of $25.4^{\circ}$. Sample P2 and P3 show similar XRD pattern. Peaks identified at $2 \theta$ values of $25.4^{\circ}, 38.1^{\circ}, 48.2^{\circ}$ and $53.9^{\circ}$, corresponding to the crystal planes 
of (101), (004), (200), and (105) respectively, which confirms the crystal phase with the standard XRD pattern of anatase $\mathrm{TiO}_{2}$ (JCPDS files No. 21-1272). Sample $\mathrm{H} 1\left(196{ }^{\circ} \mathrm{C}\right)$ and $\mathrm{H} 2\left(264^{\circ} \mathrm{C}\right)$ are amorphous, as the XRD spectra shown in Figure 5b. Sample H3 (322 $\left.{ }^{\circ} \mathrm{C}\right)$ shows weak (101) peak. By comparing above $X R D$ results of the samples respectively treated by plasma and heating, it is indicated that plasma annealing treatment is more effective in promoting the crystallization of amorphous $\mathrm{TiO}_{2}$ film than thermal treatment. Anatase $\mathrm{TiO}_{2}$ film can be obtained by atmospheric pressure RF plasma treatment for only $30 \mathrm{~min}$ at temperature of $264^{\circ} \mathrm{C}$.
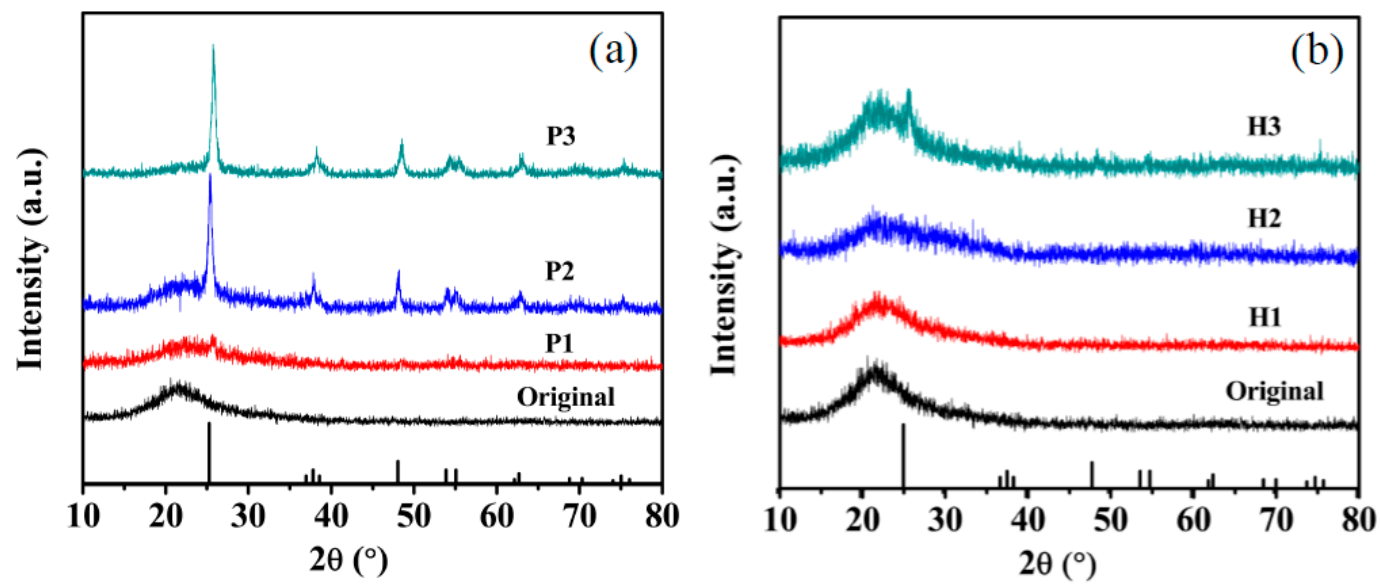

Figure 5. XRD spectra of (a) plasma treated at different power, (b) heating treated at different temperature.

Raman shift spectra were performed and the results are shown in Figure 6. As shown in Figure 6a, original sample and $\mathrm{P} 1$ are amorphous. And $\mathrm{P} 2$ and $\mathrm{P} 3$ show anatase $\mathrm{TiO}_{2}$ major Raman bands at 144, $197,399,515$, and $639 \mathrm{~cm}^{-1}$. These bands can be attributed to the five Raman-active modes of anatase phase corresponding to $\mathrm{E}_{\mathrm{g}}, \mathrm{E}_{\mathrm{g}}, \mathrm{A}_{1 \mathrm{~g}}, \mathrm{~B}_{1 \mathrm{~g}}$, and $\mathrm{E}_{\mathrm{g}}$, respectively [25]. Figure $6 \mathrm{~b}$ shows the Raman shift spectra of the samples with a different heating treatment. All the samples are amorphous. The Raman results are in well agreement with the above XRD results.
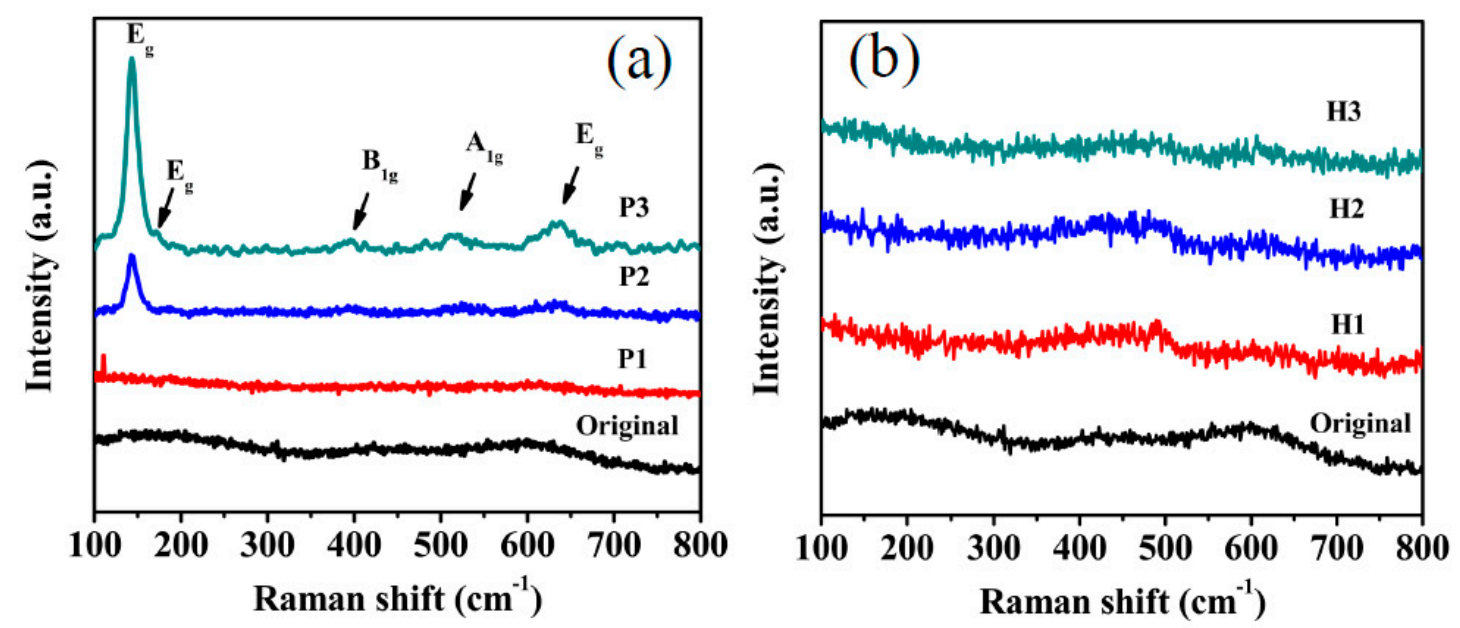

Figure 6. Raman shift spectra of (a) plasma treated at different power, (b) heating treated at different temperature.

The surface morphology of the original sample and the sample treated by plasma at $80 \mathrm{~W}$ were characterized by FE-SEM and shown in Figure 7. The original sample is fluffy. The film is made of small $\mathrm{TiO}_{2}$ particles. No clear outline of the agglomerated particles is presented and the morphology indicates poor connection between the aggregated nanoparticles. Figure $7 \mathrm{~b}$, $\mathrm{d}$ show the morphology of $\mathrm{TiO}_{2}$ thin film treated by $80 \mathrm{~W}$ RF plasma. The surface has been etching by the plasma and columnar 
$\mathrm{TiO}_{2}$ stand on the substrate. The FE-SEM results show that, the plasma has strong etching effect on amorphous $\mathrm{TiO}_{2}$ thin film.
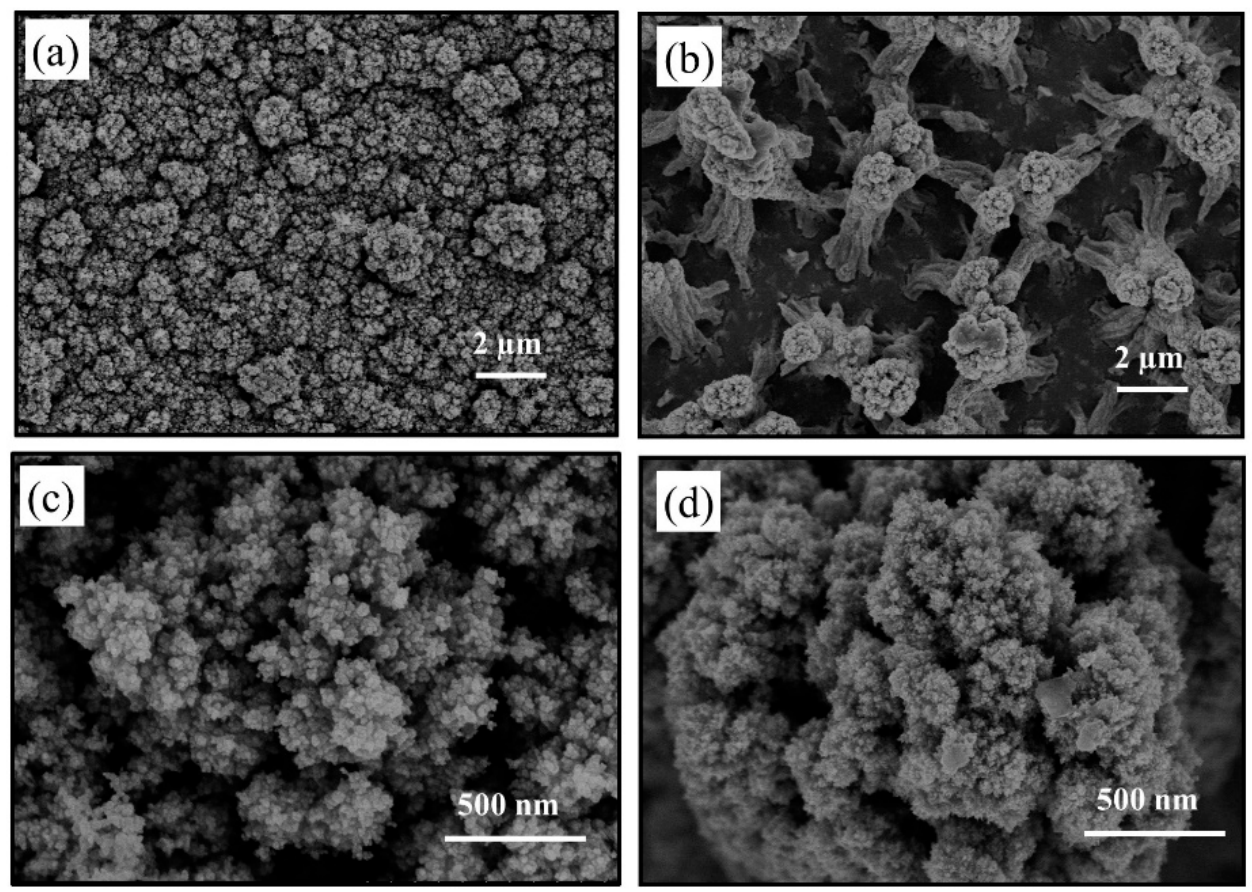

Figure 7. SEM images of (a) and (c) original sample, (b) and (d) plasma treated sample at $80 \mathrm{~W}$.

The promoting influence of $\mathrm{RF}$ atmospheric pressure plasma treatment on the crystallization of amorphous $\mathrm{TiO}_{2}$ film can be attributed to its obvious sheath structure. Plasma positive ions (such as $\mathrm{Ar}^{+}$) are accelerated through plasma sheath and will bombard the film surface directionally during the treatment [26,27]. Previous work has shown that energetic particles bombard the film and induce atomic movement. In general, amorphous phases have higher Gibb's free energy than crystalline phases. In order to reach a crystalline phase, it must overcome an activation energy barrier. In conventional furnace annealing, this energy barrier is overcome by thermal energy externally supplied. In RF plasma irradiation, however, the initial energy state is activated to a higher energy level as a result of momentum transfer from the plasma, so the activation energy barrier is reduced, as illustrated, and the film is crystallized effectively by the RF plasma irradiation [28]. Both the XRD and Raman results show similar results that the RF plasma treatment enhanced the crystallization of $\mathrm{TiO}_{2}$ film. Anatase $\mathrm{TiO}_{2}$ film was prepared at about $264{ }^{\circ} \mathrm{C}$, which is less than the usual phase change temperature $\left(450^{\circ} \mathrm{C}\right)$ from amorphous to anatase by thermal annealing. So, positive ions and their acceleration through RF plasma sheath is considered to be more effective than randomly moving neutral Ar molecules during only thermal treatment, which improves the plasma crystallization of the amorphous films possibly [29].

Figure 8 shows the photocatalytic activity of the P3 and H3. After 150 min irradiating by UV light, the MB concentration decreases to about $51 \%$ by sample P3. Sample $\mathrm{H} 3$ shows almost the result with no catalyst. As we know, the anatase shows higher photocatalytic activity than amorphous [30]. However, the photocatalytic is not outstanding comparing with well crystallized $\mathrm{TiO}_{2}$ film [19]. 


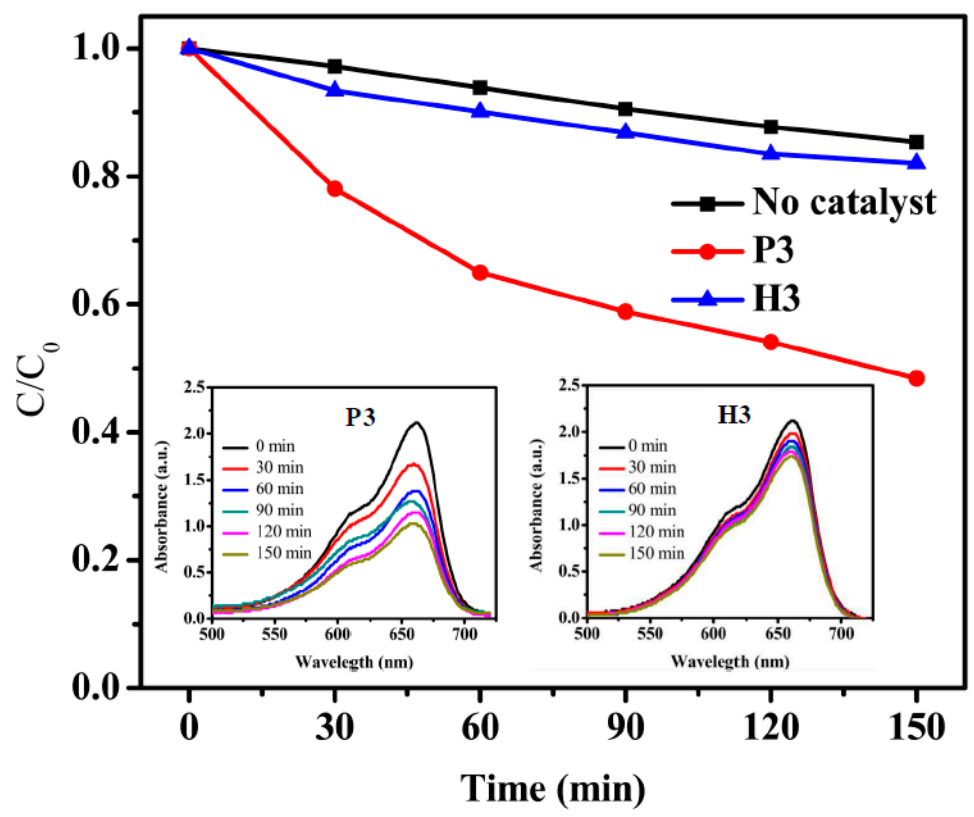

Figure 8. Results of the photocatalytic degradation of MB under UV irradiation by P3 and H3.

\section{Conclusions}

This study shows the effects of RF atmospheric pressure plasma treatment and heating annealing in the crystallization of amorphous $\mathrm{TiO}_{2}$ film. Three methods are employed to estimate the substrate temperature $T_{\mathrm{S}}$ during plasma treatment and identically close $T_{\mathrm{C}}, T_{\mathrm{o}}$ and $T_{\mathrm{n}}$ are obtained. The highest temperature is assumed not above $322^{\circ} \mathrm{C}$ at the highest discharge power of $80 \mathrm{~W}$. The amorphous $\mathrm{TiO}_{2}$ samples become to anatase after 60 and $80 \mathrm{~W}$ plasma treatment for $30 \mathrm{~min}$ (corresponding $T_{\mathrm{S}}$ is 264 and $322{ }^{\circ} \mathrm{C}$ ). However, the samples remain amorphous after the heating treatment with the same time and temperature. However, the $\mathrm{TiO}_{2}$ film was etched by the plasma treatment and some $\mathrm{TiO}_{2}$ particles have been removed from the film. Atmospheric pressure RF plasma is a prospective method for promoting the crystallization of the amorphous films at low temperature and short time.

Author Contributions: Conceptualization, J.Z. and Y.G.; Methodology, Y.X. and T.H.; Software, Y.Z. and X.H.; Validation, Y.X., J.S. and H.L.; Formal Analysis, J.Z. and K.D.; Investigation, Y.X., and Y.Z.; Resources, Y.X. and Y.G.; Data Curation, Y.X.; Writing-Original Draft Preparation, Y.X.; Writing-Review and Editing, Y.X., Y.G. and J.Z.; Visualization, Y.X.; Supervision, J.Z.; Project Administration, J.Z.; Funding Acquisition, J.Z.

Funding: This research was financially supported by Natural Science Foundation of China (Nos. 11475043, 11875104, 10835004 and 11375042).

Conflicts of Interest: The authors declare no conflict of interest.

\section{References}

1. Won, D.J.; Wang, C.H.; Jang, H.K.; Choi, D.J. Effects of thermally induced anatase-to-rutile phase transition in MOCVD-grown $\mathrm{TiO}_{2}$ films on structural and optical properties. Appl. Phys. A 2001, 73, 595-600. [CrossRef]

2. Zarubica, A.; Vasić, M.; Antonijevic, M.D.; Ranpelović, M.; Momčilović, M.; Krstić, J.; Nedeljković, J. Design and photocatalytic ability of ordered mesoporous $\mathrm{TiO}_{2}$ thin films. Mater. Res. Bull. 2014, 57, 146-151. [CrossRef]

3. Ullattila, S.G.; Periyat, P. A 'one pot' gel combustion strategy towards $\mathrm{Ti}^{3+}$ self-doped 'black' anatase $\mathrm{TiO}_{2-x}$ solar photocatalyst. J. Mater. Chem. A 2016, 4, 5854-5858. [CrossRef]

4. Yin, Z.F.; Wu, L.; Yang, H.G.; Su, Y.H. Recent progress in biomedical applications of titanium dioxide. Phys. Chem. Chem. Phys. 2013, 15, 4844-4858. [CrossRef]

5. Gan, W.Y.; Lam, S.W.; Chiang, K.; Amal, R.; Zhao, H.; Brungs, M.P. Novel $\mathrm{TiO}_{2}$ thin film with non-UV activated superwetting and antifogging behaviours. J. Mater. Chem. 2007, 17, 952-954. [CrossRef] 
6. Lee, S.Y.; Park, S.J. $\mathrm{TiO}_{2}$ photocatalyst for water treatment applications. J. Ind. Eng. Chem. 2013, 19, 1761-1769. [CrossRef]

7. Byrne, J.A.; Eggins, B.R.; Brown, N.M.D.; McKinney, B.; Rouse, M. Immobilisation of $\mathrm{TiO}_{2}$ powder for the treatment of polluted water. Appl. Catal. B Environ. 1998, 17, 25-36. [CrossRef]

8. Meng, A.; Zhang, J.; Xu, D.; Cheng, B.; Yu, J. Enhanced photocatalytic $\mathrm{H}_{2}$-production activity of anatase $\mathrm{TiO}_{2}$ nanosheet by selectively depositing dual-cocatalysts on $\{101\}$ and $\{001\}$ facets. Appl. Catal. B Environ. 2016, 198, 286-294. [CrossRef]

9. Wang, Z.; Yang, C.; Lin, T.; Yin, H.; Chen, P.; Wan, D.; Xu, F.; Huang, H.; Lin, J.; Xie, X.; et al. Visible-light photocatalytic, solar thermal and photoelectrochemical properties of aluminium-reduced black titania. Energy Environ. Sci. 2013, 6, 3007-3014. [CrossRef]

10. Lee, K.E.; Gomez, M.A.; Elouatik, S.; Demopoulos, G.P. Further Understanding of the Adsorption Mechanism of N719 Sensitizer on Anatase $\mathrm{TiO}_{2}$ Films for DSSC Applications Using Vibrational Spectroscopy and Confocal Raman Imaging. Langmuir 2010, 26, 9575-9583.

11. Liu, M.; Johnston, M.B.; Snaith, H.J. Efficient planar heterojunction perovskite solar cells by vapour deposition. Nature 2013, 5, 395-398. [CrossRef] [PubMed]

12. Hodgkinson, J.L.; Sheel, D.W. Advances in atmospheric pressure PECVD: The influence of plasma parameters on film morphology. Surf. Coat. Technol. 2013, 230, 73-76. [CrossRef]

13. Zhang, J.; Zhou, P.; Liu, J.; Yu, J. New understanding of the difference of photocatalytic activity among anatase, rutile and brookite $\mathrm{TiO}_{2}$. Phys. Chem. Chem. Phys. 2014, 16, 20382-20386. [CrossRef]

14. Ohsaki, H.; Shibayama, Y.; Yoshida, N.; Watanabe, T.; Kanemaru, S. Room-temperature crystallization of amorphous films by RF plasma treatment. Thin Solid Films 2009, 517, 3092-3095. [CrossRef]

15. Ohsaki, H.; Suzuki, M.; Shibayama, Y.; Kinbara, A.; Watanabe, T. Room temperature crystallization of indium tin oxide films on glass and polyethylene terephthalate substrates using rf plasma. J. Vac. Sci. Technol. A 2007, 25, 1052-1055. [CrossRef]

16. Ohsaki, H.; Shibayama, Y.; Nakajim, A.; Kinbara, A.; Watanabe, T. Plasma treatment for crystallization of amorphous thin films. Thin Solid Films 2006, 502, 63-66. [CrossRef]

17. Massines, F.; Sarra-Bournet, C.; Fanelli, F.; Naudé, N.; Gherardi, N. Atmospheric pressure low temperature direct plasma technology: Status and challenges for thin film deposition. Plasma Process. Polym. 2012, 9 , 1041-1073. [CrossRef]

18. Anand, V.; Nair, A.R.; Shivashankar, S.A.; Rao, G.M. Atmospheric pressure plasma chemical vapor deposition reactor for $100 \mathrm{~mm}$ wafers, optimized for minimum contamination at low gas flow rates. Appl. Phys. Lett. 2015, 107, 094103. [CrossRef]

19. Xu, Y.; Zhang, Y.; Li, L.; Ding, K.; Guo, Y.; Shi, S.; Huang, X.; Zhang, J. Synergistic effect of plasma discharge and substrate temperature in improving the crystallization of $\mathrm{TiO}_{2}$ film by atmospheric pressure plasma enhanced chemical vapor deposition. Plasma Chem. Plasma Process. 2019, 1-11. [CrossRef]

20. Zhu, W.C.; Li, Q.; Zhu, X.M.; Pu, Y.K. Characteristics of atmospheric pressure plasma jets emerging into ambient air and helium. J. Phys. D Appl. Phys. 2009, 42, 202002. [CrossRef]

21. Sharma, M.K.; Saikia, B.K.; Phukan, A.; Ganguli, B. Plasma nitriding of austenitic stainless steel in $\mathrm{N}_{2}$ and $\mathrm{N}_{2}-\mathrm{H}_{2}$ dc pulsed discharge. Surf. Coat. Technol. 2006, 201, 2407-2413. [CrossRef]

22. Saloum, S.; Naddaf, M.; Alkhaled, B. Active species characterization in RF remote oxygen plasma using actinometry OES and electrical probes. Vacuum 2010, 85, 439-442. [CrossRef]

23. Moon, S.Y.; Choe, W. A comparative study of rotational temperatures using diatomic $\mathrm{OH}, \mathrm{O}_{2}$ and $\mathrm{N}_{2}{ }^{+}$ molecular spectra emitted from atmospheric plasmas. Spectrochim. Acta Part B 2003, 58, 249-257. [CrossRef]

24. Vollmer, M. Newton's law of cooling revisited. Eur. J. Phys. 2009, 30, 1063-1084. [CrossRef]

25. Choi, H.C.; Jung, Y.M.; Kim, S.B. Size effects in the Raman spectra of $\mathrm{TiO}_{2}$ nano-particles. Vib. Spectrosc. 2005, 37, 33-38. [CrossRef]

26. Lieberman, M.A.; Lichtenberg, A.J. Principles of Plasma Discharge and Materials Processing; John Wiley \& Sons, Inc.: Hoboken, NJ, USA, 2005.

27. Han, J.; Wang, X.; Wang, N.; Wei, Z.; Yu, G.; Zhou, Z.; Wang, Q. Effect of plasma treatment on hydrophilic properties of $\mathrm{TiO}_{2}$ thin films. Surf. Coat. Technol. 2006, 200, 4876-4878. [CrossRef]

28. Kang, Y.; Lee, H.; Kang, Y.; Lee, P.S.; Lee, J. Crystallization of lithium cobalt oxide thin films by radio-frequency plasma irradiation. J. Appl. Phys. 2001, 90, 5940. [CrossRef] 
29. Sarra-Bournet, C.; Charles, C.; Boswell, R. Low temperature growth of nanocrystalline $\mathrm{TiO}_{2}$ films with $\mathrm{Ar} / \mathrm{O}_{2}$ low-field helicon plasma. Surf. Coat. Technol. 2011, 205, 3939-3946. [CrossRef]

30. Ohtani, B.; Ogawa, Y.; Nishimoto, S. Photocatalytic activity of amorphous-anatase mixture of Titanium (IV) Oxide particles suspended in aqueous solutions. J. Phys. Chem. B 1997, 101, 3746-3752. [CrossRef]

(C) 2019 by the authors. Licensee MDPI, Basel, Switzerland. This article is an open access article distributed under the terms and conditions of the Creative Commons Attribution (CC BY) license (http://creativecommons.org/licenses/by/4.0/). 